\title{
A Novel Work on Problems Faced by Freight Forwarders with Reference to Yashimarine Logistics
}

\author{
J. Pavithra, Kavitha P, Venkatraman S
}

\begin{abstract}
Cold chains are typical in the sustenance and pharmaceutical endeavors and besides in some engineered shipments. One fundamental temperature go for an infection chain in pharmaceutical organizations is 2 to $8^{\circ} \mathrm{C}$. be that as it may, the specific temperature (and time at temperature) versatilities depend upon the genuine thing being sent. Exceptional to fresh create cargoes, the infection chain requires to moreover keep up thing express condition parameters which consolidate air quality levels (carbon dioxide, oxygen, moisture and others), which makes this the most tangled infection chain to work. Through this examination, the researcher endeavors to recognize the key areas to be moved up to improve the general adequacy of the infection chain collaborations for pharmaceutical things like antibodies. The general target of this examination is to evaluate the issues looked by cargo forwarders in virus chain supply coordinations on security of antibodies in pharmaceutical merchants. Different destinations are to decide how stockpiling conditions in pharmaceutical wholesalers impacts wellbeing of immunizations, assess the impact of bundling in pharmaceutical merchants on the security of antibodies and to set up the degree to which specialized limit in pharmaceutical merchants impact security of Vaccines.
\end{abstract}

Keywords: Immunization, Pharmaceutical Organizations, Infection.

\section{INTRODUCTION}

An infection chain is a watched temperature-controlled creation arrange. The target of the infection chain is to keep a model or material inside a particular temperature go during all periods of movement, taking care of and limit .Cold chains are commonly used to ensure the reasonableness of things in the pharmaceutical and country territories, and are essential sections of inoculation programs and bio-therapeutic observation works out[1],[3],[5].

Various characteristic models separate when displayed to warmth, sunlight, or splendid light. When moving and securing such common substances, it is fundamental that field and research office gatherings control natural

Revised Manuscript Received on July 22, 2019.

J. Pavithra Department of MBA, Bharath Institute of Higher Education and Research, Chennai, India

Email: pavithralect@yahoo.com

Kavitha .P, Department of Information Technology, Bharath Institute of Higher Education and Research, Chennai, India.

Email: varshinikavitha@gmail.com

Venkatraman S, Department of Civil Engineering, Bharath Institute of

Higher Education and Research, Chennai, India.

Email: mailmagik@yahoo.com conditions, ensuring that introduction to possibly hurting environmental components is constrained[2],[4],[6].

The chilly stockpiling, dealing with, and dissemination of temperature-delicate medications speak to an undeniably significant segment of the worldwide pharmaceutical inventory network. Clinical preliminary material (CTM) or investigational restorative items (IMP) are a significant piece of the most punctual phases of the existence science inventory network. Given the expanded number of worldwide administrative and benchmarks based direction archives issued in the course of recent years, individuals from the pharmaceutical store network are paying heed and making changes to guarantee item quality and ensure quiet wellbeing.

Cold Chain is an arrangement of putting away and moving antibody at the prescribed temperature run from the purpose of production to purpose of utilization[7],[9],[11]. The virus chain framework and antibody stream in the nation:- The immunizations are shipped from the producer through air transport under the temperature scope of $2-8 \mathrm{oC}$ to the essential immunization stores (GMSDs/State head quarter).

\section{SAMPLE SIZE}

A Sample frame may be defined as the listing of the general components of the individual units that comprise the defined population.

Table - 1 The Major Issue For The Transport Problems In Cold Chain Supply Logistics In Pharmaceutical Industry

\begin{tabular}{|l|l|l|}
\hline Particulars planning for & No. of Respondents & \% of Respondents \\
\hline $\begin{array}{l}\text { Lack of chain } \\
\text { maintenance and cold chation } \\
\text { rehabilitation for }\end{array}$ & 25 & $25 \%$ \\
\hline $\begin{array}{l}\text { Incorrect use of the Vaccines } \\
\text { Vial Monitor (VVM) as a } \\
\text { management tool }\end{array}$ & 27 & $32 \%$ \\
\hline $\begin{array}{l}\text { Lack of planning } \\
\text { emergencies }\end{array}$ & 16 & $27 \%$ \\
\hline $\begin{array}{l}\text { Frequent breakdowns in cold } \\
\text { chain }\end{array}$ & $\mathbf{1 0 0}$ & $16 \%$ \\
\hline Total & $\mathbf{1 0 0} \%$ \\
\hline
\end{tabular}

Inference:

$32 \%$ of the respondents notice that the wrong utilization of the Vaccines Vial Monitor (VVM) as an administration device causes the serious issue for the vehicle issues in virus 
chain supply coordinations in pharmaceutical industry,

$27 \%$ of the respondents notice that the absence of making arrangements for crises causes the serious issue for the vehicle issues in virus chain supply coordinations in pharmaceutical industry, $25 \%$ of the respondents notice that the absence of getting ready for upkeep and cold chain recovery causes the serious issue for the vehicle issues in virus chain supply coordinations in pharmaceutical industry, $16 \%$ of the respondents notice that the continuous breakdowns in virus chain causes the serious issue for the vehicle issues in virus chain supply coordinations in pharmaceutical industry.

In this way $32 \%$ of the respondents notice that the mistaken utilization of the Vaccines Vial Monitor (VVM) as an administration apparatus causes the serious issue for the vehicle issues in virus chain supply coordinations in pharmaceutical industry

Table - 2 Transport Systems Influence The Safety Of Vaccines In Pharmaceutical Distributors

\begin{tabular}{|l|l|l|}
\hline Particulars & No. of Respondents & \% of Respondents \\
\hline Strongly agree & 27 & $27 \%$ \\
\hline Agree & 29 & $29 \%$ \\
\hline Neutral & 25 & $25 \%$ \\
\hline Disagree & 10 & $10 \%$ \\
\hline Strongly Disagree & 9 & $9 \%$ \\
\hline Total & $\mathbf{1 0 0}$ & $\mathbf{1 0 0 \%}$ \\
\hline
\end{tabular}

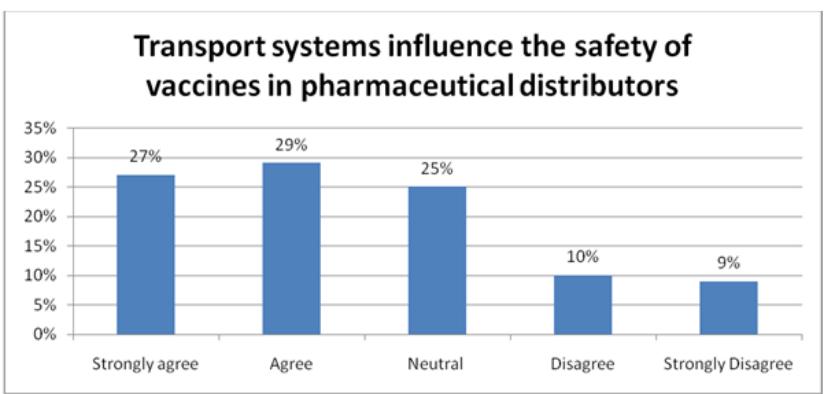

Figure 2-2 Transport Systems Influence The Safety Of Vaccines In Pharmaceutical Distributors

Table - 3 Ranks The Problems Faced From Carriers During Cold Chain Supply Logistics In Maintaining The Safety Of Vaccines

\begin{tabular}{|l|l|l|}
\hline Particulars & $\begin{array}{l}\text { No. of } \\
\text { Respondents }\end{array}$ & of Respondents \\
\hline Delivery delay & 13 & $13 \%$ \\
\hline Damaging of packages & 21 & $21 \%$ \\
\hline Frequent rise in forwarding cost & 17 & $17 \%$ \\
\hline Lack of proper communication & 19 & $19 \%$ \\
\hline Bulk- Order Priority & 40 & $40 \%$ \\
\hline Total & $\mathbf{1 0 0}$ & $\mathbf{1 0 0} \%$ \\
\hline
\end{tabular}

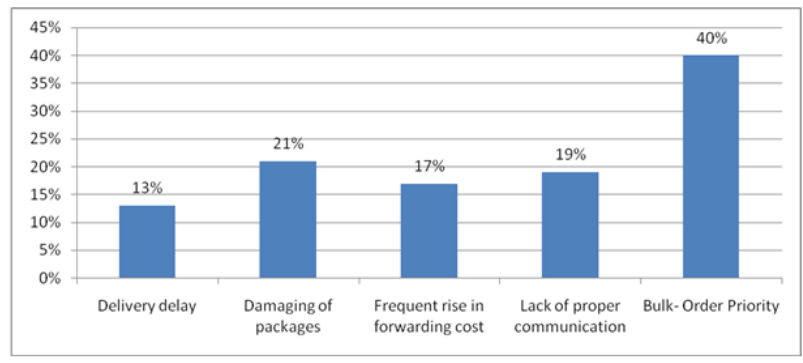

Figure - 3 Ranks The Problems Faced From Carriers During Cold Chain Supply Logistics In Maintaining The Safety Of Vaccines

\section{A. Chi Square Test}

Case Processing Summary

\begin{tabular}{|l|l|l|l|l|l|l|}
\hline & \multicolumn{5}{|l|}{ Cases } & \multicolumn{5}{l|}{ Missing } & \multicolumn{2}{l|}{ Total } \\
\cline { 2 - 7 } & \multicolumn{2}{|l|}{ Valid } & \multicolumn{2}{l|}{} \\
\cline { 2 - 7 } & $\mathrm{N}$ & Percent & $\mathrm{N}$ & Percent & $\mathrm{N}$ & Percent \\
\hline $\begin{array}{l}\text { EXPERIENCE } \\
\text { INCOME }\end{array}$ & 100 & $100.0 \%$ & 0 & $.0 \%$ & 100 & $100.0 \%$ \\
\hline
\end{tabular}






\begin{tabular}{|c|c|c|c|c|c|c|c|c|}
\hline & \multirow{6}{*}{$\begin{array}{l}6.1-1 \\
\text { years }\end{array}$} & Covet & & \multirow{3}{*}{$0 \%$} & \multirow{3}{*}{$\begin{array}{l}1 \\
100 \%\end{array}$} & \multirow{3}{*}{$900 \%$} & \multirow{3}{*}{$.0 \%$} & \multirow{3}{*}{$\begin{array}{l}10 \\
100.0 \\
\%\end{array}$} \\
\hline & & $\% \quad$ mithin & & & & & & \\
\hline & & $\begin{array}{l}\text { EXPERIENC } \\
\text { E }\end{array}$ & & & & & & \\
\hline & & $\% \quad$ within & $.0 \%$ & $.0 \%$ & $5.9 \%$ & $900 \%$ & $.0 \%$ & 10.0 \\
\hline & & INCOME & & & & & & $\%$ \\
\hline & & $\%$ of Total & $.0 \%$ & $.0 \%$ & $1.0 \%$ & $9.0 \%$ & $.0 \%$ & 10.0 \\
\hline & \multirow{2}{*}{\multicolumn{2}{|c|}{ More than Covet }} & & & & & & \\
\hline & & & 0 & 0 & 0 & 1 & 6 & 7 \\
\hline & \multirow[t]{6}{*}{10 Years } & $\% \quad$ within & $.0 \%$ & $.0 \%$ & $.0 \%$ & $14.3 \%$ & $85.7 \%$ & 1000 \\
\hline & & EXPERIENC & & & & & & $\%$ \\
\hline & & & & & & & & \\
\hline & & $\%$ within & $.0 \%$ & $.0 \%$ & $.0 \%$ & $100 \%$ & $100.0 \%$ & $7.0 \%$ \\
\hline & & DNCOME & & & & & & \\
\hline & & $\%$ of Toal & $.0 \%$ & $.0 \%$ & $.0 \%$ & $1.0 \%$ & $6.0 \%$ & $7.0 \%$ \\
\hline \multirow[t]{6}{*}{ Toal } & & Covat & 26 & 41 & 17 & 10 & 6 & 100 \\
\hline & & within & $260 \%$ & $41.0 \%$ & $17.0 \%$ & $10.0 \%$ & $6.0 \%$ & 1000 \\
\hline & & $\begin{array}{l}\text { EXPERIENC } \\
\text { E }\end{array}$ & & & & & & $\%$ \\
\hline & & $\% \quad$ within & $1000 \%$ & $1000 \%$ & $1000 \%$ & $1000 \%$ & $1000 \%$ & 100.0 \\
\hline & & DNCOME & & & & & & $\%$ \\
\hline & & $\%$ of Total & $26.0 \%$ & $41.0 \%$ & $17.0 \%$ & $100 \%$ & $6.0 \%$ & 100.0 \\
\hline
\end{tabular}

\begin{tabular}{|l|l|l|l|}
\hline & Value & df & $\begin{array}{l}\text { Asymp. Sig. } \\
\text { (2-sided) }\end{array}$ \\
\hline Pearson Chi-Square & $348.695^{\mathrm{a}}$ & 16 & .000 \\
Likelihood Ratio & 252.024 & 16 & .000 \\
Linear-by-Linear & 96.062 & 1 & .000 \\
Association & & & \\
N of Valid Cases & 100 & & \\
\hline
\end{tabular}

a. 19 cells $(76.0 \%)$ have expected count less than 5 . The minimum expected count is .42 .

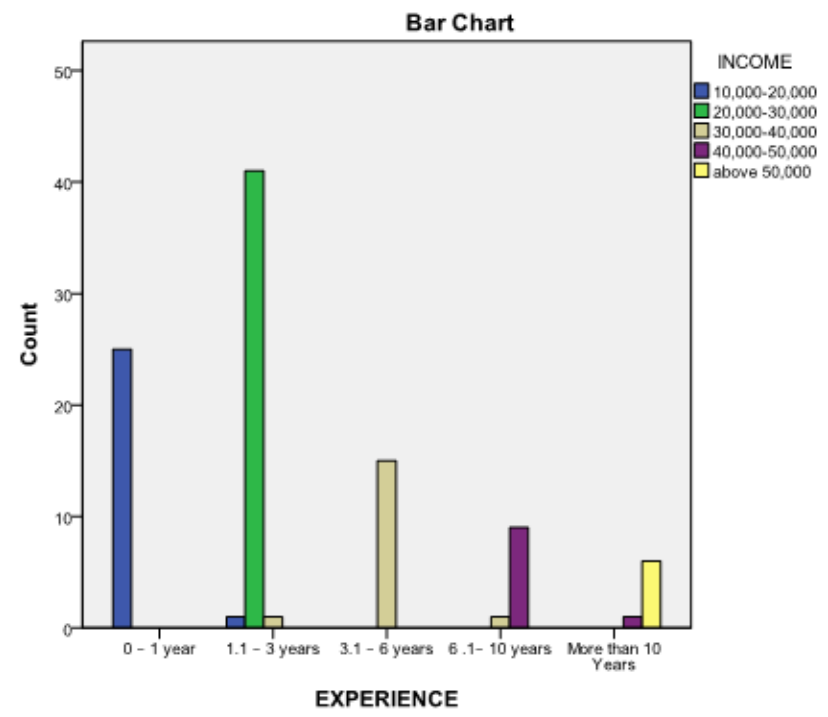

Degree of Freedom $=(\mathrm{r}-1) *(\mathrm{c}-1)$

$$
=4 * 4=16
$$

Calculated value $=348.695$

Tabulated value $=\mathbf{2 6 . 2 9 6}$

$\mathrm{Z}=\mathrm{Z}$ cal $>\mathrm{Z}$ tab

\section{$\mathrm{Z}=348.695>26.296$}

Hence, the Alternate hypothesis [H1] is accepted

\section{INFERENCE:}

Since the calculated value is greater than the tabulated value, we accept the alternate hypothesis and hence there is a relationship between the Experience and Income.

\section{B. One-Way Anova Classification}

Table - 4Transport systems influence the safety of vaccines in pharmaceutical distributors

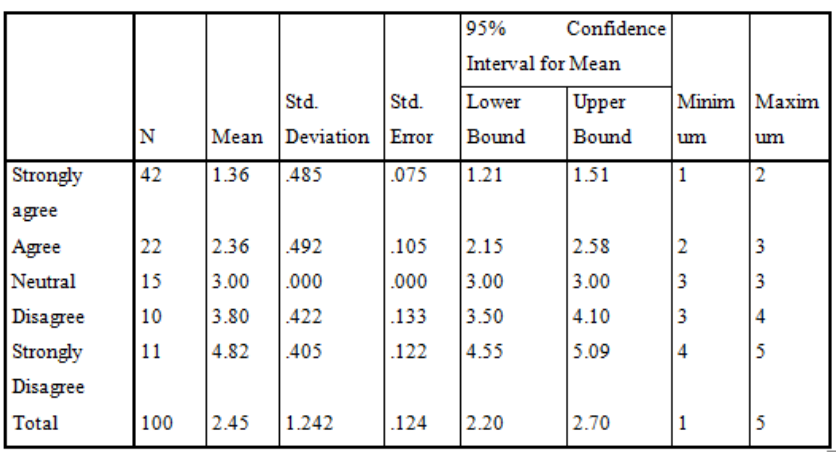

\section{Test of Homogeneity of Variances}

Table - 5 Transport systems influence the safety of vaccines in pharmaceutical distributors

\begin{tabular}{|l|l|l|l|}
\hline $\begin{array}{l}\text { Levene } \\
\text { Statistic }\end{array}$ & df1 & df2 & Sig. \\
\hline 26.161 & 4 & 95 & .000 \\
\hline
\end{tabular}

\section{ANOVA}

Transport systems influence the safety of vaccines in pharmaceutical distributors

\begin{tabular}{|l|l|l|l|l|l|}
\hline & $\begin{array}{l}\text { Sum of } \\
\text { Squares }\end{array}$ & df & $\begin{array}{l}\text { Mean } \\
\text { Square }\end{array}$ & F & Sig. \\
\hline Between & 134.780 & 4 & 33.695 & 178.130 & .000 \\
Groups & & 95 & .189 & & \\
Within Groups & 17.970 & 95 & & & \\
Total & 152.750 & 99 & & & \\
\hline
\end{tabular}

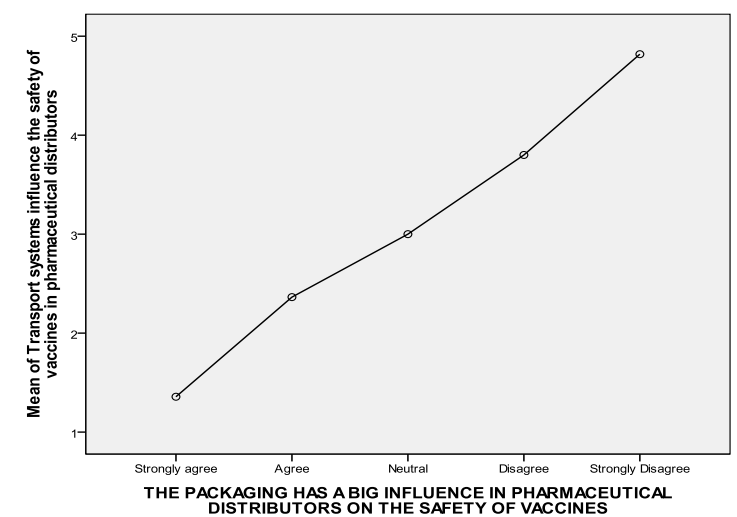

Calculated value $=\mathbf{1 7 8 . 1 3 0}$

Tabulated value $=\mathbf{2 . 4 7}$ 
$\mathrm{F}=\mathrm{F}$ cal $>\mathrm{F}$ tab $\quad \mathrm{F}=178.130>2.47$

Hence, the Alternate hypothesis [H1] is accepted.

\section{INFERENCE}

The calculated value of $F$ is greater than the tabulated value. Hence, we reject the null hypothesis and conclude that there is no significance difference between the Transport systems influence the safety of vaccines in pharmaceutical distributors and the packaging has a big influence in pharmaceutical distributors on the safety of vaccines.

\section{Correlations}

\begin{tabular}{|c|c|c|}
\hline & \begin{tabular}{|l} 
THE \\
MAJOR \\
PURPOSE \\
OF COLD \\
CHAIN \\
SUPPLY \\
LOGISTICS \\
IN \\
PHARMAC \\
EUTICAL \\
INDUSTRY
\end{tabular} & $\begin{array}{l}\text { THE MAIN } \\
\text { OBJECTIVE } \\
\text { OF COLD } \\
\text { CHAIN } \\
\text { SUPPLY } \\
\text { LOGISTICS } \\
\text { IN } \\
\text { PHARMAC } \\
\text { EUTICAL } \\
\text { INDUSTRY }\end{array}$ \\
\hline 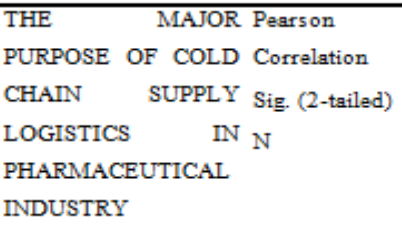 & 100 & $\begin{array}{l}.913^{\prime \prime} \\
.000 \\
100\end{array}$ \\
\hline $\begin{array}{lr}\text { THE } & \text { MAIN Pearson } \\
\text { OBJECTIVE } & \text { OF Correlation } \\
\text { COLD } & \text { CHAIN } \\
\text { Sig. (2-tailed) } \\
\text { SUPPLY LOGISTICS } \mathrm{N} \\
\text { IN } \\
\text { PHARMACEUTICAL } \\
\text { INDUSTRY }\end{array}$ & $\begin{array}{l}.913^{\circ} \\
.000 \\
100\end{array}$ & 100 \\
\hline
\end{tabular}

**. Correlation is significant at the 0.01 level (2-tailed).

$$
\begin{aligned}
& r=\frac{N \sum X Y-\sum X \sum Y}{\sqrt{N \sum X^{2}-\left(\sum X\right)^{2}} \sqrt{N \sum Y^{2}-\left(\sum Y\right)^{2}}} \\
& r=.913
\end{aligned}
$$

\section{INFERENCE}

Since $r$ is positive, there is positive relationship between the major purpose of cold chain supply logistics in pharmaceutical industry and the main objective of cold chain supply logistics in pharmaceutical industry.

\section{RESULTS}

Therefore a large portion of the respondents have a place with age bunch 20-30.

- Therefore the greater part of the respondents are male.

- Therefore the greater part of the respondents are graduate[8],[10],[12].

- Therefore a large portion of the respondents have $1.1-3$ years experience.
- Therefore the greater part of the respondents are procuring 20,000-30,000.

- Therefore the greater part of the respondents state that keep up the temperature level for the immunizations.

- Therefore the greater part of the respondents are Increase consumer loyalty.

- Therefore the greater part of the respondents are erroneous utilization of the Vaccines Vial Monitor (VVM) as an administration device.

- Therefore the vast majority of the respondents are Both Refrigerated distribution center and Refrigerated transportation[13], [15],[17].

- Therefore the vast majority of the respondents are Agree with Transport frameworks impact the wellbeing of antibodies in pharmaceutical merchants.

- Therefore the vast majority of the respondents are Bulk-Order Priority.

- Therefore the vast majority of the respondents are Refrigerated vehicle.

- Therefore the greater part of the respondents are Reefers.

\section{DISCUSSIONS}

1. Yashimarine coordinations needs to improve their getting ready for crises

2. Necessary estimates should be taken for upkeep and cold chain recovery[14],[16], [18]

3. Frequent breakdowns in virus chain has be maintained a strategic distance from to improve the general effectiveness of virus chain coordinations in taking care of pharmaceutical items

4. Frequent ascent in sending cost can be stayed away from by owning the virus chain transportation and the chilly stockpiling.

5. Government can take appropriate activities to diminish the high vitality cost. This will help Yashimarine coordinations associated with virus tie coordinations to diminish their expense. At the point when both the cost decreases occur, the end clients can benefit the pharmaceutical items at a lesser cost[19],[21],[23]

6. Incorrect utilization of the Vaccines Vial Monitor (VVM) as an administration instrument has be maintained a strategic distance from. Legitimate procedure must be pursued during the general virus chain coordinations for antibodies.

\section{V.CONCLUSION}

Cold chains are basic in the nourishment and pharmaceutical businesses and furthermore in some compound shipments. There have been various occasions where immunizations have been transported to underdeveloped nations with practically zero virus chain framework (Sub-Sahara Africa) where the antibodies were inactivated because of abundance presentation to warm[25],[27],[29].

This investigation has been embraced to evaluate the practicality in taking care of the pharmaceutical items like 
immunizations in virus chain coordinations with uncommon reference to Yashimarine coordinations.

For this reason, reactions from the individuals engaged with virus chain coordinations have been gathered and dissected. In view of the discoveries out of the examination, couple of profitable recommendations like legitimate utilization of Vaccines Vial Monitor (VVM) as an administration apparatus, improve the getting ready for crises and so forth have been proposed to Yashimarine coordinations[31],[33]. These recommendations will clear route for improving the general proficiency of the virus chain coordinations for pharmaceutical items like immunizations.

\section{REFERENCES}

1) BharthVajan R., Ramachandran S.,Psychographic dimensions of training,2016,International Journal of Pharmacy and Technology,V-8,I-4,P-23727-23729

2) Balakrishnan P., Bharthvajan R.,A study on human resource planning in hospitals in Chennai City,2014,International Journal of Applied Engineering Research,V-9,I-22,P-7503-7507

3) Priyadarsini P., Bharthvajan R.,Role of emotional intelligence training programme in reducing the stress of the nurses,2014,International Journal of Applied Engineering Research,V-9,I-22,P-7411-7421

4) Kerinab Beenu G., Bharthvajan R.,Empirical analysis on the cosmetic buying behavior of young women in South India,2014,International Journal of Applied Engineering Research,V-9,I-22,P-7361-7366

5) Balakrishnan P., Bharthvajan R.,Whistling in the wind,2014,International Journal of Applied Engineering Research,V-9,I-22,P-7586-7593

6) Krishnan B., Peter M.,Health hazards of Indian Bpo employee-an alarming issue,2014,International Journal of Applied Engineering Research,V-9,I-22,P-7336-7341

7) Kerinab Beenu G.H., Peter M.,Role of insurance in economic development,2014,International Journal of Applied Engineering Research,V-9,I-22,P-7532-7539

8) Balakrishnan P., Peter M., Priyadarsini P.,Efficiency of safety measures for wellbeing of employees in manufacturing industry,2014,International Journal of Applied Engineering Research,V-9,I-22,P-7376-7382

9) Anbarasi M., Praveen Kumar S.,Online sales promotions of herbal products and its effectiveness towards tanisha.com,2019,Indian Journal of Public Health Research and Development,V-10,I-1,P-195-200

10) Anbarasi M., Praveen Kumar S.,Various online marketing and promotions strategies to improve the validation towards the organic products in the pharmaceutical sectors,2019,Indian Journal of Public Health Research and Development, V-10,I-1,P-263-269

11) Loganathan R., Praveen Kumar S.,Grievance handling a key factor for solving issues of employees in an organization,2014,International Journal of Applied Engineering Research,V-9,I-22,P-7483-7491

12) Loganathan R., Praveen Kumar S.,Study on preference of private label brands in super and Hypermarkets,2014,International Journal of Applied Engineering Research,V-9,I-22,P-7327-7335

13) Smitha M., Praveen Kumar S.,Understanding stress and its managementamong the nurses in Chennai city,2014,International Journal of Applied Engineering Research,V-9,I-22,P-7560-7565

14) Kerinab Beenu G.H., Praveen Kumar S.,A study on the investment behavior of Chennai investors in mutual fund schemes,2014,International Journal of Applied Engineering Research,V-9,I-22,P-7520-7525

15) Loganathan R., Praveen Kumar S.,Retention strategies key for organizational productivity,2014,International Journal of Applied Engineering Research,V-9,I-22,P-7443-7447

16) Pavithra J., Ganesan M., Brindha G.,State wise analysis of microfinance sector in India,2016,International Journal of Pharmacy and Technology,V-8,I-4,P-23417-23432

17) Pavithra J., Ganesan M.,A comparative study on microfinance in India and abroad,2016,International Journal of Applied Business and Economic Research,V-14,I-8,P-5471-5476

18) Pavithra J., Ganesan M.,A study on awareness and impact of micro-financial schemes,2016,International Journal of Applied Business and Economic Research,V-14,I-8,P-5449-5460

19) Senthilmurugan P., Pavithra J.,Consumer preference towards organised retailing with reference to Big Bazaar,2014,International Journal of Applied Engineering Research,V-9,I-22,P-7469-7475
20) Senthilmurugan P., Pavithra J.,Implication of social media marketing in growing healthcare industry,2014,International Journal of Applied Engineering Research,V-9,I-22,P-7448-7456

21) Loganathan R., Pavithra J.,Consumer perception towards private label brand over other brands in super markets and hypermarkets,2014,International Journal of Applied Engineering Research,V-9,I-22,P-7355-7360

22) Kerinab Beenu G., Pavithra J.,Tradeâ€"off between liquidity and profitability in logistics industry,2014,International Journal of Applied Engineering Research,V-9,I-22,P-7398-7401

23) Kerinab Beenu G., Pavithra J.,A study on the prospective consumerâ $€^{\mathrm{TM}_{S}}$ perception towards utility cars in Chennai city,2014,International Journal of Applied Engineering Research,V-9,I-22,P-7526-7531

24) Pavithra J., Dilli Babu P., Ambuli T.V.,A study on budgetary control at Maruti Service Masters, Chennai,2014,International Journal of Applied Business and Economic Research,V-12,I-2,P-151-161

25) Pavithra J., Dilli Babu P., Ambuli T.V.,A study on customer satisfaction of retro Garments Pvt Ltd, Chennai,2014,International Journal of Applied Business and Economic Research,V-12,I-2,P-381-391

26) Kerinab Beenu G.H., Pavithra J., Senthilmurugan P.,A study on the influence of promotional activities for TATA ARIA among consumers in Chennai,2014,International Journal of Applied Engineering Research,V-9,I-22,P-7572-7578

27) Vijayaragavan S.P.,An investigative expert that's general FBG sensors,International Journal of Mechanical Engineering and Technology,V-8,I-8,PP-1500-1505,Y-2017

28) Vijayaragavan S.P.,Equalization routing protocol for $\mathrm{Wi}-\mathrm{Fi}$ sensor strategy,International Journal of Mechanical Engineering and Technology,V-8,I-8,PP-1662-1666,Y-2017

29) Karthik B., Kiran Kumar T.V.U., Vijayaragavan P., Bharath Kumaran E.,Design of a digital PLL using 0.35 $\hat{\mathrm{I}}^{1} / \mathrm{m}$ CMOS technology,Middle East Journal of Scientific Research,V-18,I-12,PP-1803-1806,Y-2013

30) Kanniga E., Selvaramarathnam K., Sundararajan M.,Kandigital bike operating system,Middle - East Journal of Scientific Research,V

31) Jasmin M., Vigneshwaran T., Beulah Hemalatha S.,Design of power aware on chip embedded memory based FSM encoding in FPGA,International Journal of Applied Engineering Research,V-10,I-2,PP-4487-4496,Y-2015

32) Jasmin M.,Optimization techniques for low power VLSI circuits,Middle East Journal of Scientific Research,V-20,I-9,PP-1082-1087,Y-2014

33) Jasmin M., Vigneswaran T.,Fuzzy controller for error control of on - Chip communication,2017 International Conference on Algorithms, Methodology, Models and Applications in Emerging Technologies, ICAMMAET 2017,V-2017-January,I-,PP-1-5,Y-2017

\section{AUTHORS PROFILE}

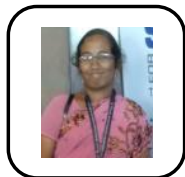

J. Pavithra Assistant Professor, Department of MBA, Bharath Institute of Higher Education and Research, Chennai, India.

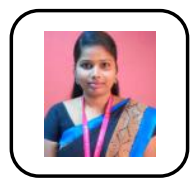

Kavitha .P Assistant Professor, Department of Information Technology, Bharath Institute of Higher Education and Research, Chennai, India.

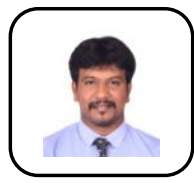

Venkatraman S Assistant Professor, Department of Civi Engineering, Bharath Institute of Higher Education and Research, Chennai, India. 